\title{
A study of Competency-based Approach to Identify High Performers among Disaster Management Professionals
}

\author{
SURBHI SAXENA ${ }^{1}$, HARMINDER KAUR GUJRAL ${ }^{2}$, SUDHANSU PATHAK ${ }^{3}$ \\ ${ }^{1}$ Amity Business School, AMITY UNIVERSITY, NOIDA \\ E-mail: surbhisaxena1212@gmail.com \\ ${ }^{2}$ Amity Business School, AMITY UNIVERSITY, NOIDA \\ E-mail: hkgujral@amity.edu \\ ${ }^{3}$ Head- HR \& OD, JK TYRE \& INDUSTRIES LTD., DELH \\ E-mail: drpathak.sudhansu@gmail.com
}

\begin{abstract}
In today's times, while measuring an organization's performance in terms of best results, productivity, and profits, more and more is referred not to the material resources, but to the human resources and their competencies in terms of knowledge, skills and attitudes. The human resource management system is a process of making people and organizations come together so that the objectives of each other are met with a win-win approach. Competency is an underlying feature of an individual which enables him/her to deliver superior performance in a given job, role or any situation. Competency mapping is one of the prominent human resource management initiatives to identify the knowledge, skills and attributes required to perform a job effectively and efficiently in the best possible manner. At present, development of competencies has become one of the key priorities of organizations. It is also important to realize the factors responsible for the enhancement of the competencies to ensure the high performance of the employees. This calls for the Human resource management to initiate competency mapping and identifying the skills affecting the employee's performance at the workplace. Nowadays, most of the organizations are utilizing competency mapping as a tool to identify high performers. The present study focuses on identifying the competencies for Disaster management professionals that enhance their performance in the management of disasters. The study describes the main goal of conducting competency mapping and how it influences the performance of disaster management professionals. The overall objective of the study is to explore the factors which ensure the high performance of disaster management professionals. The study validates that competency-based management and related HR practices are gaining momentum in the field of the Disaster Management sector in the context of performance management of the disaster management professionals.
\end{abstract}

Keywords: Competency mapping; Competency-based management; Skills; Performance management; Disaster.

JEL Classification: C1, M1

Received: July 29, 2021

Accepted: September 18, 2021 


\title{
Un Estudio sobre el Enfoque basado en las Competencias para Identificar a los Profesionales de la Gestión de Catástrofes de Alto Rendimiento
}

\author{
SURBHI SAXENA ${ }^{1}$, HARMINDER KAUR GUJRAL ${ }^{2}$, SUDHANSU PATHAK ${ }^{3}$ \\ ${ }^{1}$ Amity Business School, AMITY UNIVERSITY, NOIDA \\ E-mail: surbhisaxena1212@gmail.com \\ ${ }^{2}$ Amity Business School, AMITY UNIVERSITY, NOIDA \\ E-mail: hkgujral@amity.edu \\ ${ }^{3}$ Head- HR \& OD, JK TYRE \& INDUSTRIES LTD., DELHI \\ E-mail: drpathak.sudhansu@gmail.com
}

\begin{abstract}
RESUMEN
En los tiempos actuales, al medir el rendimiento de una organización en términos de mejores resultados, productividad y beneficios, cada vez se hace más referencia no a los recursos materiales, sino a los recursos humanos y sus competencias en términos de conocimientos, habilidades y actitudes. El sistema de gestión de los recursos humanos es un proceso que hace que las personas y las organizaciones se unan para que los objetivos de cada una se cumplan con un enfoque en el que todos salgan ganando. La competencia es una característica subyacente de un individuo que le permite ofrecer un rendimiento superior en un determinado trabajo, función o cualquier situación. El mapeo de competencias es una de las principales iniciativas de gestión de recursos humanos para identificar los conocimientos, las habilidades y los atributos necesarios para desempeñar un trabajo de forma eficaz y eficiente de la mejor manera posible. En la actualidad, el desarrollo de las competencias se ha convertido en una de las prioridades clave de las organizaciones. También es importante conocer los factores responsables de la mejora de las competencias para garantizar el alto rendimiento de los empleados. Esto exige que la gestión de los recursos humanos inicie el mapeo de competencias e identifique las habilidades que afectan al rendimiento de los empleados en el lugar de trabajo. Hoy en día, la mayoría de las organizaciones utilizan el mapeo de competencias como herramienta para identificar a los empleados de alto rendimiento. El presente estudio se centra en la identificación de las competencias de los profesionales de la gestión de catástrofes que mejoran su rendimiento en la gestión de las mismas. El estudio describe el objetivo principal de realizar un mapa de competencias y cómo influye en el rendimiento de los profesionales de la gestión de catástrofes. El objetivo general del estudio es explorar los factores que garantizan el alto rendimiento de los profesionales de la gestión de catástrofes. El estudio valida que la gestión basada en las competencias y las prácticas de RRHH relacionadas con ella están cobrando impulso en el ámbito del sector de la gestión de catástrofes en el contexto de la gestión del rendimiento de los profesionales de la gestión de catástrofes.
\end{abstract}

Palabras clave: Mapeo de competencias; Gestión por competencias; Habilidades; Gestión del rendimiento; Catástrofes.

Clasificación JEL: C1, M1

Recibido: 29 de Julio de 2021

Aceptado: 18 de Septiembre de 2021 


\section{Introduction}

Competency is a fundamental characteristic of an individual which enable ones to bring superior performance in a given job, role or situation. Competency may be defined as the capability of an individual to do a job perfectly. Competencies are the knowledge, skills and attitudes required by an individual to perform a job, task, or assignment. According to McClelland (1973), "a competency is defined as an underlying characteristic of a person which enables them to deliver superior performance in a given job, role, or situation."

Competency mapping means exploring the underlying key characteristics and behaviours which leads to high performance and attainment of the set targets and deliverables. Competency mapping is a process of identifying the gap of an individual's performance or job-related skills to fill those gaps through effective training. According to Yuvaraj (2011), competency mapping identifies an individual's strengths and weaknesses to help better understand themselves and it describes what has to be done to overcome the weaknesses and nurture one's strengths. Competency-based HR systems specially developed for recruiting applications and software comprises competencies used to recruit, place and promote employees with the right skills and capabilities at right time to help the organisation gain a competitive edge over its competitors. In the case of training and development of the employees, it helps the supervisors and HR department to identify gaps in every employee's competency, capabilities, skills, attitude which can be corrected by designing appropriate tailor-made training programmes. Also, in the case of performance management, competency mapping results could be assessed and utilized for identifying and filling the gaps in the required competencies for expected high performance.

For organizations to become high-performing, it is important and essential to have a competencybased performance management system as part of their overall competency management plan. With a competency-based performance management system in place, the Human Resource department of the organizations can better motivate their employees, design career advancement and growth plans, align training programmes with the organizational and employee goals, clearly define job description chart i.e., roles, responsibilities and skills needed to perform each job effectively and efficiently, as well as improve the recruitment process and increase the employee retention in the organization.

\section{Literature review-Competency-Based Approach for Performance Management}

A competent workforce is the main foundation for cultivating a performance-oriented climate in an organizational setup. Competency management includes two main concepts "competence" and "competences". Many researchers define these terms differently. Zeer et al. (2005) state that "competence of a person is his knowledge, skills, abilities and experience, ability to mobilize those knowledge, abilities and experience in social and professional situations". According to him, "competences are generalized ways of actions providing productive performance in professional activity". Barbera et al. (2005) define competency as a "specific capability required for effective performance, within the context of a job's responsibilities, which achieves the objectives of the organization". Srividya \& Basu (2015) identified that competencies like interpersonal relationship, team building and collaboration and learning aptitude are the vital components of the competency.

Any competent employee should essentially have a set of non-compromisable professional competencies in the absence of which optimum performance will not be feasible. However, just having professional competence is not sufficient to meet the expectations of any organization. Today's organizations expect effective and outstanding performance from their employees. Thus, certain set of behavioural competencies are basically required which will help the professionals to use their knowledge and skills appropriately and will facilitate the high performance and attainment of the outcomes of their work more effectively. These behavioural competencies were studied in view of the competency-based approach of Boyatzis (1982), who defines competency as a capability or ability to perform a role. It is a set of related but different sets of behaviours organized around an underlying construct, called the "intent". He proposed a model for the theory of action and job performance to 
explain the situations under which it is possible to expect effective performance from the employees. Boyatzis emphasized the overlapping of the two components of the model. According to him, the higher is the overlapping in the model higher is the chance for effective performance. He added if the components do not overlap it may be detrimental to the performance. According to the Theory of Performance (Boyatzis, 1982) Fig.1, the best fit refers to the full performance, external and internal stimulation, dedication and commitment which is represented by the area of maximum overlap or integration in figure 1 below.

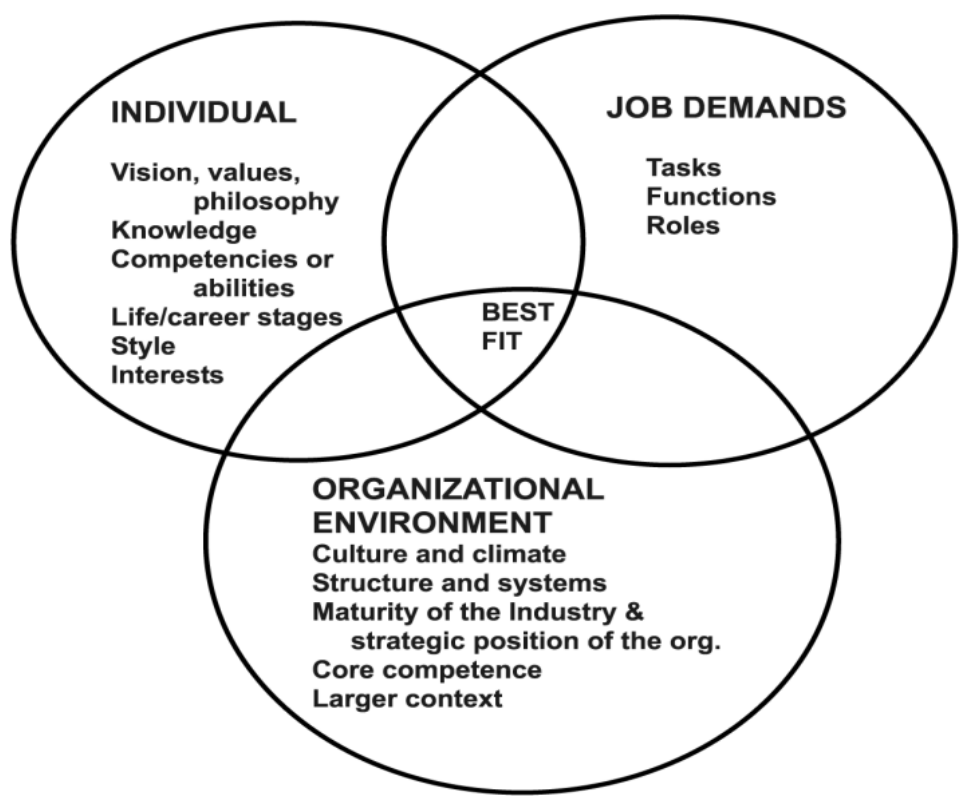

Figure 1: Boyatzis model of effective job performance

This model depicts that employee high performance is based on the right combination of three important factors which include Individual Competencies, Job demands and Organizational environment. The individual competencies include vision, values. knowledge and skills, Job demands include tasks, functions, roles, technical skills and organizational environment include culture and climate, structures and systems etc.

Sarkar (2014) stressed that a competence-based management system helps the organizations to decide and plan for learning and development for the employees and identifies a set of possible resources and supports the organizations to identify talents with the required set of competencies.

Smith and Rutigliano (2003) stated that various competencies forecast the performance levels across the individuals in the same roles and responsibilities, owing to the fact that the level of competency in a person affects one's behaviour and performance.

Sanghi (2012) stated that the main objective of performance management is to encourage all employees to understand that how important it is for them to enhance their performance, upgrade their skills and knowledge, improve the level of job satisfaction, and know their full potential so as to benefit themselves as well as the organisation. Performance management is about the understanding and attainment of the results in line with the organizational expectations and fulfilment of the selfsatisfaction by the employee. The linking of performance with competencies helps individuals in understanding their job requirements and enhancing competencies for best results. Many researchers are of the opinion that competencies are important for excellent performance. Few researchers equate competencies equal to performance however others feel that competencies cannot alone guarantee performance.

Smithesh \& Shameem (2018) explored the importance and role of competency-based management in performance appraisal, selection and hiring. According to the study, it is always vital for the organization to anticipate and manage competencies well in advance by the HR departments. 
Rao (2004) in his effective performance equation showed that with motivation, full support from the organization and the opportunity given at any workplace together with skills, knowledge and ability of the employees results in effective performance. According to Rao's effective performance equation:

"Individual performance = ability *motivation *organizational support + or - chance"

The very characteristic and nature of jobs of disaster management professionals are becoming more and more complex day by day with a strong alignment towards collaboration and networking. The core competencies vital to effectively carry out their jobs are manifold and multidimensional (Bullock et al., 2006; Kapucu \& Van Wart, 2006; Rubin, 2007)

Kappu (2011) in his article emphasized that the unprecedented nature of disasters and difficulty in their management, disaster management has become a field needing a variety of competencies. According to him, the disaster management competencies can be categorized into two groups i.e., intra-organizational and inter-organizational. While the intra-organizational competencies include important issues with the perspective of the organization e.g., organizational management, technological competency, and comprehensive and supported decision making, the interorganizational competencies incorporates issues pertaining to leadership, liasioning networking, coordination, and collaboration of the professionals among themselves and others.

Performance measurement is an approach adopted in organizations for identifying the outcomes and targets and determining the way forward toward achieving the identified outcomes and targets. Superior performance is the end result or the outcome which can be evaluated through the competency-based performance management system (Boyatzis, 2008; Abraham et al., 2001).

Sinha et al., (2016) in an exploratory study "Applying Competency Mapping in the Information Technology Sector "concluded that there exists a strong and positive association between competencies possessed by an individual and his successful performance in the job. They emphasized that competencies and competency models are among the most appropriate and accurate tools to prepare for the current and future workforce and retain skilled employees to meet the job requirements.

Saxena \& Gujral (2020) in their study "Managerial Competencies and Demographic Characteristics: A Study on Middle-level Disaster Management professionals of Delhi" revealed that competencies are underlying characteristics of an individual and are significantly related to demographic characteristics like gender, age, education, experience and length of service.

Gillani et al (2020) in a study, "Evaluation of Disaster Medicine Preparedness among Healthcare Profession Students: A Cross-Sectional Study in Pakistan" observed that demographic factors like age, gender, academic year, university have a reasonable impact on the knowledge, attitude and willingness towards the practice of the healthcare students in universities in Pakistan.

\section{Statement of problem}

Competency mapping not only leads to performance excellence but also helps to identify the gaps in performance. To minimize the impact of disasters on mankind, it is important to possess and utilize technical skills, knowledge and behavioural skills. The effectiveness of Disaster management professionals to manage disasters depends not only on the competencies like their technical abilities and knowledge but also certain behavioural factors, team effectiveness and attitude in serving the affected communities. At times, it becomes difficult to analyze which skill to nurture more when compared with other skills, as all seem to be important. At this juncture, it becomes important to identify the most appropriate mix of the said competencies i.e., technical and soft skills to be possessed by the disaster management Professionals, ensuring their best performance during managing any disastrous situation. Also, it becomes imperative to identify the organizational factors which may lead to better performance. The present study aims to explore the most precise combination of the important competencies to be possessed by disaster management professionals. The study also intends to identify how a competency-based approach towards performance management could be used to identify superior performers. Therefore, it also becomes important to identify the relevant 
skills in the disaster management domain that would help the prospective disaster management professionals to gain better insight for managing the disasters effectively and efficiently.

\section{Objectives of the study}

$>$ To understand the impact of the organizational environment on the performance of disaster management professionals.

$>$ To explore the effect of technical skills possessed by the disaster management professionals on their performance

$>$ To study the effect of interpersonal skills on performance of the disaster management professionals

$>$ To give an overview of the required skills to be possessed by the professionals working in the disaster management domain.

\section{Hypotheses Statement}

The following hypotheses had been formulated and tested in the context of the present study $H(1)$ - Organizational environment has a significant effect on an individual's performance $\mathrm{H}(2)$-Technical skills have significant effect on an individual's performance $H(3)$-Interpersonal skills have a significant effect on an individual's performance.

\section{Research methodology}

The research design in the study is descriptive in nature. In order to identify the skill-set requirements for the high performance of disaster management professionals, a qualitative research study was followed. The qualitative research was done through literature review, the study of role profiles and job descriptions. The appreciative inquiry was conducted with the supervisors and heads of the professionals to understand the job skills and competencies required to do the jobs. The qualitative research helped in the identification of the work circumstance, the requirement of technical, communication, verbal, reasoning and teamwork skills.

The respondents selected for the present study include 117 disaster management professionals working with various organizations in the disaster management sector in Delhi-NCR. The sampling technique used in the study is convenience sampling. The tool used for conducting this study comprised of a well-structured survey questionnaire containing 45 questions and was divided into the following four parts to fulfil the objectives of the research:

$\checkmark$ Personal information

$\checkmark$ Technical skills possessed by disaster management professionals for high performance of the disaster management professionals

$\checkmark$ Behavioural skills possessed by disaster management professionals for high performance

$\checkmark$ Organizational environment supportive for high performance

The questionnaire had 15 variables which were tested for the research hypotheses through ANOVA keeping in mind the independent and dependent variables. The independent variables in the study majorly comprised of the organizational environment, technical and behavioural skills possessed by the Disaster management professionals which were further segregated into different components based on the hypothesis. The dependent variable taken in the study is the performance of the disaster management professionals. The primary data was collected through a questionnaire and secondary data was collected from various journals, websites and books.

\section{Sample Profile}

Out of 117 respondents, there were 79 males and 38 females working at the middle level as disaster management professionals. Most of the respondents were in the age range of 25-45 years of age. 81 were postgraduates remaining i.e., 36 possessed the diploma or any other similar qualification. The experience of the respondents varies from 3-20 years with an average experience of 6.78 years. 


\section{Data Analysis}

The findings mentioned below are based on the hypotheses framed

\subsection{Hypothesis 1}

$H(0)$ - Organizational environment has no significant effect on an individual's performance.

$\mathrm{H}(1)$ - Organizational environment has significant effect on an individual's performance.

Analysis of Variance (ANOVA) test was conducted to test hypothesis 1 that whether the organizational environment has significant effect on the individual's performance or not. For testing performance against the organizational environment, the independent variable selected is "Prompt response to the disaster". In the disaster management sector, prompt response to disasters cannot be compromised and is one of the biggest parameters of performance hence this variable was selected as independent variable for testing hypothesis 1 . The dependent variables taken were related to the organization's efforts in capacitating an individual towards progressive growth and which reflects the individual's readiness to perform in that condition. The dependent variables are:

$\checkmark \quad$ I usually put in more effort than required.

$\checkmark$ My employer gives me a chance to challenge my limits.

$\checkmark \quad$ I am often felt inspired and motivated to find an unusual solution to the problem.

$\checkmark$ The organisation encourages the best in me by way of job performance.

$\checkmark \quad$ The organisation values me and my skills.

The results of the ANOVA test conducted for hypothesis 1 is as follows: -

Table 1: ANOVA

$H(0)$ : Organizational environment has no significant effect on an individual's performance

\begin{tabular}{|l|c|c|c|c|c|}
\hline & $\begin{array}{c}\text { Sum of } \\
\text { squares }\end{array}$ & $\mathrm{df}$ & $\begin{array}{c}\text { Mean } \\
\text { square }\end{array}$ & $\mathrm{F}$ & Sig. \\
\hline $\begin{array}{l}\text { I usually put in more effort than } \\
\text { required }\end{array}$ & 35.884 & 4 & 8.971 & 8.757 & $<.001$ \\
\hline $\begin{array}{l}\text { My employer gives me a chance to } \\
\text { challenge my limits }\end{array}$ & 49.694 & 4 & 12.42 & 9.315 & $<.001$ \\
\hline $\begin{array}{l}\text { I am often felt inspired and } \\
\text { motivated to find an unusual } \\
\text { solution to the problem. }\end{array}$ & 42.649 & 4 & 10.66 & 9.521 & $<.001$ \\
\hline $\begin{array}{l}\text { The organisation encourages the } \\
\text { best in me by way of job } \\
\text { performance. }\end{array}$ & 56.762 & 4 & 14.19 & 13.33 & $<.001$ \\
\hline $\begin{array}{l}\text { The organisation values me and } \\
\text { my skills }\end{array}$ & 48.782 & 4 & 13.12 & 9.451 & $<.001$ \\
\hline
\end{tabular}

\subsubsection{Interpretation}

It is clear from the above ANOVA table 1, the significance of variables is less than the acceptable limit of $<=.005$. Therefore, the alternate hypothesis $H(1)$ is accepted and the null hypothesis $H(0)$ is rejected. From the above table, it could be inferred that an organization's environment has a significant effect on the performance of an individual.

\subsection{Hypothesis 2}

$H(0)$ - Technical competency has no significant effect on an individual's performance

$\mathrm{H}(2)$-Technical competency has significant effect on an individual's performance.

For testing the hypothesis of whether the technical competencies of the Disaster management professionals had any significant effect on an individual's performance or not, ANOVA test was 
conducted through SPSS. For testing performance against technical competencies possessed by the disaster management professionals, the independent variable selected is "Accuracy in the assessment of risks, vulnerability and impact of a disaster". The dependent variables selected were:

1. I manage information in a structured and systematic manner,

2. I actively participate in mock drill exercises.

3. I attend trainings and keep myself updated

4. I prioritize tasks and follow time management.

5. I possess the required analytical skills and is action-oriented

The results of the ANOVA test conducted for hypothesis 2 is as follows: -

Table 2: ANOVA

$H(0)$ - Technical competency has no significant effect on an individual's performance

\begin{tabular}{|l|c|c|c|c|c|}
\hline & $\begin{array}{c}\text { Sum of } \\
\text { squares }\end{array}$ & $\mathrm{df}$ & Mean square & $\mathrm{F}$ & Sig. \\
\hline $\begin{array}{l}\text { I manage information in a } \\
\text { structured and systematic manner }\end{array}$ & 58.219 & 4 & 14.555 & 11.64 & $<.001$ \\
\hline $\begin{array}{l}\text { I actively participate in mock drill } \\
\text { exercises }\end{array}$ & 50.578 & 4 & 12.645 & 15.16 & $<.001$ \\
\hline $\begin{array}{l}\text { I attend trainings and keep myself } \\
\text { updated }\end{array}$ & 56.34 & 4 & 12.431 & 14.15 & $<.001$ \\
\hline $\begin{array}{l}\text { I prioritize task and follow time } \\
\text { management }\end{array}$ & 54.62 & 4 & 13.262 & 13.45 & $<.001$ \\
\hline $\begin{array}{l}\text { I possess the required analytical } \\
\text { skills and is action-oriented }\end{array}$ & 53.98 & 4 & 14.487 & 12.98 & $<.001$ \\
\hline
\end{tabular}

\subsubsection{Interpretation}

From the ANOVA table above, it is inferred that there is a statistically significant as the $p$-value falls within the acceptable range of $<=.005$. Therefore, the alternate Hypothesis $H(2)$ i.e. Technical competency has significant effect on an individual's performance is accepted and the null Hypothesis $H(0)$ - Technical competency has no significant effect on an individual's performance stands rejected. Thus, it could be inferred that the technical competencies are not compromised and are essential for the efficient management of disasters.

\subsection{Hypothesis 3}

$H(0)$-Interpersonal skills has no significant effect on an individual's performance.

$\mathrm{H}(3)$-Interpersonal skills have a significant effect on an individual's performance.

Analysis of Variance (ANOVA) test was conducted to test hypothesis 3 whether the interpersonal skills had a significant impact on an individual's performance or not. For testing performance against interpersonal competencies possessed by the disaster management professionals, the independent variable selected is "Coordinating communication and teamwork in the disasters". The dependent variables selected were:

1. I value relationships and networking

2. I believe in creative thinking and constantly strive for improvement.

3. I appreciate teamwork.

4. My role requires vast communication skills.

5. I am flexible enough to accommodate change.

The results of the ANOVA test conducted for hypothesis 3 is as follows: - 
Table 3: ANOVA

$H(0)$ - Interpersonal skills has no significant effect on an individual's performance.

\begin{tabular}{|l|c|c|c|c|c|}
\hline & $\begin{array}{c}\text { Sum of } \\
\text { squares }\end{array}$ & $\mathrm{df}$ & Mean square & $\mathrm{F}$ & Sig. \\
\hline $\begin{array}{l}\text { I value relationships and } \\
\text { networking }\end{array}$ & 20.304 & 4 & 5.076 & 3.68 & .005 \\
\hline $\begin{array}{l}\text { I believe in creative thinking and } \\
\text { constantly strive for } \\
\text { improvement }\end{array}$ & 62.391 & 4 & 15.598 & 11.1 & $<.001$ \\
\hline I appreciate teamwork. & 31.995 & 4 & 7.999 & 7.23 & $<.001$ \\
\hline $\begin{array}{l}\text { My role requires vast } \\
\text { communication skills }\end{array}$ & 68.172 & 4 & 17.042 & 13 & $<.001$ \\
\hline $\begin{array}{l}\text { I am flexible enough to } \\
\text { accommodate change }\end{array}$ & 65.871 & 4 & 10.16 & 14.91 & $<.001$ \\
\hline
\end{tabular}

\subsubsection{Interpretation}

The results from the above ANOVA table 3 depicts that the level of significance falls within the acceptable range of $<=.005$. Therefore, it could be inferred that the Interpersonal skills do have a significant impact on the performance of disaster management professionals. Thus, the alternate hypothesis i.e., Interpersonal skills possessed by the disaster management professionals has a significant effect on an individual's performance, is accepted and the null hypothesis $H(0)$ i.e., Interpersonal skills has no significant effect on an individual's performance, is rejected.

\section{Findings and Discussion}

The first objective of the research is to understand the impact of the organizational environment on the performance of disaster management professionals. Based on the ANOVA test result in table 1, it clearly signifies that the organizational environment has a positive impact on the overall performance of the disaster management professionals. The respondents feel motivated and take initiative if allowed to work in an open environment where challenges are addressed adequately. A positive, encouraging, and open environment motivates its employees to solve unprecedented problems during disasters in an effective manner. A constructive organizational climate leads to a higher level of organizational commitment and high performance along with enhanced job satisfaction. The results also revealed the role of positive organizational climate and enhancement in the leadership skills of the employees and improved performance. The results of this study are also in line with the study conducted by Isci et al., (2015). The work environment plays a crucial role which raises the employee morale, efficiency and satisfaction to get motivated for performing better on the job.

The second objective of the research is to explore the effect of technical skills possessed by disaster management professionals on their performance.

The results of the ANOVA table 2 shows that the technical competencies have significant effect on an individual's performance. Respondents feel that it is important to be technically sound to efficiently and effectively cater to the needs arising out of unprecedented disastrous situations. The respondents also consent to the importance of maintaining a structured and organized database that may be utilized promptly by the disaster management professionals at the outset of disasters. Respondents agrees that the skills in time management and organization are crucial. According to Flint \& Brennan (2006) in a study on "Community emergency response teams: From disaster responders to community builders" concluded that to assist and help the victims of any disaster, it is crucial to possess the basic technical skills which include providing early warning, logistics and communication, search and rescue, database management and team organization.

The third objective of the research is to study the effect of interpersonal skills on performance of the disaster management professionals. 
On the basis of test results from the ANOVA table, it is apparent that interpersonal skills contribute significantly to the performance of disaster management professionals. These skills include communication, relationship and networking, teamwork and flexibility. All the respondents consented that presence of the interpersonal skills is very essential in the management of disasters. Oloruntoba (2005), explored that during any emergency, effective collaboration between the parties including the local population, local government authorities and humanitarian organizations is an indispensable part of the disaster management and needed the coordinated efforts of all key stakeholders. Further, Kuntz et al (2008) concluded in their study that during a disaster, there is a need for many teams to come together to help victims, which requires collaboration and effective communication to reduce the morbidity and mortality of the victims.

The fourth objective of the research is to provide an overview of the required skills to be possessed by the professionals working in the disaster management domain.

Based on the response from the respondents which were disaster management professionals employed in Delhi-NCR, literature review and appreciative inquiry with the heads and supervisors of the disaster management professionals engaged in the Disaster management domain, it can be inferred that all the three main skills namely the organizational, technical and interpersonal skills are important and contribute significantly to the performance of the disaster management professionals in Delhi NCR.

The organizational competencies include creating a constructive environment, open and positive environment for the employees to work. It is the responsibility of heads and supervisors to contribute to building such a positive climate and motivate and raise the morale of their subordinates. Regular interaction with the subordinates, sharing of ideas and knowledge will ensure the high performance of the disaster management Professionals.

Technical skills are required to gain accuracy in the assessment of risks, vulnerability and impact of disasters. According to Green et al., 2003 regular organizing and active participation in the disaster management simulation exercises and drills are beneficial for the expansion of knowledge and skills to be able to act in real-time situations. This practice is widely used throughout the world as a fundamental tool for the evaluation and improvement of disaster response mechanisms and capacities of the different participating stakeholders. Therefore, it is crucial to upgrade technical skills.

No matter how much the Disaster management sector gives importance to technical skills, but interpersonal skills cannot be compromised. communication, teamwork, flexibility and other such interpersonal skills have now been acknowledged as these are the skills without which even the application of technical skills is not appraised nowadays. Pittiway, Bartolomei and Rees (2007) conducted a study in which the authors found that good interpersonal and communication skills among disaster agencies and disaster victims will help disaster victims to prepare and become more attentive and prepared before the disaster happens. The study also revealed that good communication will help victims recover from psychological problems like stress, trauma and other psychological effects that have been caused by the disaster. Thus, it can be concluded that interpersonal competencies have significant effect on the performance of disaster management professionals in Delhi-NCR.

With the organizational support and adoption of best HR practices for the achievement of projected goals and objectives, the performance of the employee remains the single most important factor that decides the successful delivery of the tasks in the disaster management sector (Saxena et al.,2016). Often, being the collective efforts culminating into the result in this sector, the high performers remain as a mix with the average performers and simple spectators in the team. In such a scenario, it becomes important to identify and acknowledge such high performers not only to keep their motivation level high but also to develop them as role models and future leaders. The competencies, driving these professionals to deliver superior performance, are required to be identified. Competency mapping which is an important tool of best HR management practices can be an effective process to measure and map those competencies and combine them with other required skills. The results of competency mapping of superior performers can be incorporated in the performance assessment process and can 
be used to enhance the overall performance of the organisation and facilitate the conduct of disaster management practices in a more effective, efficient and time-driven manner. This study validates that the competency mapping process of high performers of disaster management professionals has been largely instrumental for competency-based HR practices gaining momentum in this sector.

\section{Conclusion}

The purpose of this research was to examine the effect of organizational environment, technical and interpersonal skills on the overall performance of disaster management Professionals in Delhi NCR. The study revealed the various competencies required by disaster management professionals to perform effectively and efficiently with the main aim to reduce morbidity and mortality to mankind during any disaster. The study also disclosed that the organizational, technical and interpersonal competencies contribute significantly towards the performance of disaster management professionals in Delhi -NCR. The present study justifies that by following the competency-based approach in the organizations it is easy to boost the performance and morale of the employees. The present study successfully establishes that having the right blend of a positive organisation environment, updated knowledge and adequate technical skills with strong communication, teamwork and good interpersonal competencies, will surely result in the superior performance of disaster management professionals in the disaster management sector in Delhi NCR.

\section{Limitations of the study}

This study is limited to explore the contribution of a competency-based approach to the overall performance of the disaster management professionals in Delhi- NCR. The survey aimed to identify the impact of competency mapping with reference to three variables namely Organizational environment, technical skills and interpersonal skills whereas there are several other competencies (emotional, social and cognitive intelligence) that affect the performance, which is not included.

\section{References}

1. Abraham, S.E., Karns, L.A., Shaw, K. and Mena, M.A. (2001). Managerial competencies and the managerial performance appraisal process. Journal of Management Development, Vol. 20 No. 10, pp. 842-852.

2. Barbera, J. A., Macintyre, A. G., Shaw, G., Seefried, V., Westerman, L., \& deCosmos, S. (2005). VHAEMA emergency response and recovery competencies survey, analysis, and report. Retrieved from http://training.fema.gov/EMIWeb/edu/EMCompetencies.asp

3. Boyatzis Richard E. (2008). Competencies in the 21st century. Journal of Management Development Vol. 27 No. 1, pp. 5-12.

4. Boyatzis, R E. (1982). The Competent Manager: A Model for Effective Performance. New York: John Wiley \& Sons, $\mathrm{pp}$ 46-48.

5. Bullock, J. A., Haddow, G. D., Coppola, D., Erdem, E., Westerman, L., \& Yeletaysi, S. (2006). Introduction to homeland security. Burlington, VT: Elsevier Inc.

6. Flint, C., \& Brennan, M. (2006). Community emergency response teams: From disaster responders to community builders. Journal of Volunteer A Disaster Management administration, 1, 1-9.

7. Gillani Ali Hassan, Izham Mohamed, Akbar Jamshaid, Yu Fang (2020). Evaluation of Disaster Medicine Preparedness among Healthcare Profession Students: A Cross Sectional Study in Pakistan. Journal of Environmental Research and Public Health, 17, 2027; doi:10.3390/ijerph17062027

8. Green, G. B., Modi, S., lunney, K., \& Thomas, T. I. (2003). Generic evaluation methods for disaster drills in developing countries. Annals of Emergency medicine, 41, 689-699.

9. Isci Sabiha, Cakmak Esra, Karadag Engin (2015). The effect of leadership on organizational climate. Springer International Publishing Switzerland.

10.Kapucu, N., \& Van Wart, M. (2006). The emerging role of the public sector in managing extreme events: Lessons learned. A Disaster Management administration and Society, 38(3), 279-308. 
11.Knuntz, S. W., Frable, P., Qureshi, K., \& Strong, L. L. (2008). Association of community health nursing educators: Disaster preparedness white paper for community/public health nursing educators. Public Health Nursing, 25, 362-369.

12.McClelland, D.C. (1973). Testing for competence rather than for "intelligence". American Psychologist, 28(1), 1-14.

13.McClelland, D.C. (1973). Testing for competence rather than intelligence. American Psychologist, XXVIII, (1), pp. 1- 40.

14.Naim Kappu, (2011). Developing Competency-Based Emergency Management Degree Programs in Public Affairs and A Disaster Management administration. Journal of Public Affairs Education . January 2011

15.Oloruntoba, R., (2005). A wave of destruction and the waves of relief: issues, challenges and strategies: Disaster Prevention and Management. Annual International Journal, 4, 506-21.

16.Pittiway, E., Bartolomei, L., \& Rees, S. (2007). Gendered dimensions of the 2004 tsunami and a potential social work response in post-disaster situations. International Social Work, 50(3), 307-319

17.Rao T.V. (2004). Performance Management and Appraisal Systems. Sage Response Books, New Delhi, pp 6, 9

18.Rubin, C. (Ed.).(2007). Emergency management: The American experience 1900-2005. Fairfax, VA: Public Entity Risk Institute.

19.Sanghi Seema (2012). Developing Competency Model. The Handbook of Competency Mapping Understanding, Designing and Implementing Competency, Models in Organizations, Sage Publications India.

20.Sarkar, S. (2014). Competency Mapping- Rejuvenating Knowledge-based Development. Drishtikon: A Journal of Management, Symbiosis Centre for Management \& Human Resource Development Online access @www.publishingindia.com, pp. 435-464.

21.Saxena Surbhi, Gujral H. K \& Sehgal Aarti (2016). Competency based management as an effective tool for sustainable organizational performance and development. IC- DEBPRDE - Development of Economies through Business Process Re-Engineering in Digital Era, ISBN 9789385777615, pp 101105.

22.Saxena Surbhi Gujral H. K. (2020). Managerial Competencies and Demographic Characteristics: A Study on Middle-level Disaster Management professionals of Delhi. European Journal of Molecular \& Clinical Medicine ISSN 2515-8260 Volume 7, Issue 11.

23.Sinha Deepti, Sinha Sachin, Singh Kalpana (2016). Applying Competency Mapping in the Information Technology. Amity Global HRM Review, Vol 6, pp 86-94.

24.Smith, B., \& Rutigliano, T. (2003). Incompetencies. Gallup Management Journal August 14(1). Retrieved 7 October 2014, from http://www.gallup.com/businessjournal/1171/ incompetencies.aspx.

25.Smithesh G. \& Shameem A. (2018). A Study on Competency Mapping and its Impact on Deliverables with respect to the Realty Sector. International Journal of Civil Engineering and Technology (IJCIET) Volume 9, Issue 1, January 2018, pp. 179-190, Article ID: IJCIET_09_01_018 Available online at http://http://iaeme.com/Home/issue/IJCIET?Volume=9\&Issue=1 ISSN Print: 0976-6308 and ISSN Online: 0976-6316.

26.Srividya, N. \& Basu, R. (2015). Competency Mapping Correctional Officers. SCMS Journal of Indian Management, January - March, pp. 88-96.

27.Yuvaraj. R (2011). Competency mapping - A Drive for Indian Industries. International Journal of Scientific and Engineering Research, volume 2, issue 8.

28.Zeer E.F., Pavlova A.M., Symanyuk E.E. (2005). Modernization of professional education: competency-based approach. Studies. grant. M, 2005. pp.216. 